\title{
Recent advances in solid oxide cell technology for electrolysis
}

Hauch, Anne; Küngas, R; Blennow, P; Hansen, A B; Hansen, J B; Mathiesen, B V; Mogensen, Mogens Bjerg

\section{Published in:}

Science

Link to article, DOI:

10.1126/science.aba6118

Publication date:

2020

Document Version

Peer reviewed version

Link back to DTU Orbit

Citation (APA):

Hauch, A., Küngas, R., Blennow, P., Hansen, A. B., Hansen, J. B., Mathiesen, B. V., \& Mogensen, M. B. (2020). Recent advances in solid oxide cell technology for electrolysis. Science, 370(6513), eaba6118-eaba6118. https://doi.org/10.1126/science.aba6118

\section{General rights}

Copyright and moral rights for the publications made accessible in the public portal are retained by the authors and/or other copyright owners and it is a condition of accessing publications that users recognise and abide by the legal requirements associated with these rights.

- Users may download and print one copy of any publication from the public portal for the purpose of private study or research.

- You may not further distribute the material or use it for any profit-making activity or commercial gain

- You may freely distribute the URL identifying the publication in the public portal

If you believe that this document breaches copyright please contact us providing details, and we will remove access to the work immediately and investigate your claim 


\title{
Recent advances in solid oxide cell technology for electrolysis
}

Authors: A. Hauch ${ }^{1 * \dagger}$, R. Küngas ${ }^{2 \dagger}$, P. Blennow ${ }^{2 \ddagger}$, A. B. Hansen ${ }^{3 \ddagger}$, J. B. Hansen ${ }^{2 \ddagger}$, B.V. Mathiesen $^{4 \ddagger}$ and M. B. Mogensen ${ }^{1 \ddagger}$

Affiliations:

${ }^{1}$ Department of Energy Conversion and Storage, Technical University of Denmark, Fysikvej, Building 310, DK-2800 Kgs. Lyngby, Denmark

${ }^{2}$ Haldor Topsoe A/S, Haldor Topsøes Allé 1, DK-2800 Kgs. Lyngby, Denmark

${ }^{3}$ Energinet.dk, Tonne Kjærsvej 65, DK-7000 Fredericia, Denmark

${ }^{4}$ Department of Planning, The Technical Faculty of IT and Design, Aalborg University, A.C. Meyers Vænge 15.A, DK-2450 Copenhagen SV, Denmark

*Correspondence to: Anne Hauch, hauc@dtu.dk

$\dagger$ Equal contributions

\$Equal contributions

\section{One sentence summary}

High temperature ceramic electrolyzers can unlock the full potential of renewables and provide climate-friendly fuels.

\begin{abstract}
In a world powered by intermittent renewable energy, electrolyzers will play a central role converting electrical energy into chemical energy, thereby decoupling the production of transport fuels and chemicals from today's fossil resources and decreasing the reliance on bioenergy. Solid oxide electrolysis cells (SOECs) offer two major advantages over alternative electrolysis technologies. First, the high operating temperatures result in favorable thermodynamics and reaction kinetics, enabling unrivaled conversion efficiencies. Second, SOECs can be thermally integrated with downstream chemical syntheses, such as the production of methanol, dimethyl ether, synthetic fuels or ammonia. SOEC technology has witnessed tremendous improvements during the past 10 to 15 years, and is approaching maturity, driven by improvements at the cell-, stack- and system-level.
\end{abstract}




\section{Structured Abstract \\ BACKGROUND}

Alleviating the worst effects of climate change requires drastic modification of our energy system, moving from fossil fuels to low-carbon energy sources. The challenge is not the amount of renewable energy available - energy potential from solar and wind exceeds global energy consumption many times. Rather the key to a $100 \%$ renewable energy supply lies in the integration of the growing share of intermittent sources into a power infrastructure that can meet continuous demand. The higher the share of renewables, the more flexible and interconnected the energy system (electric grid, gas network, heat network) needs to be. Critically, a future energy system where the supply of electricity, heat, and fuels is based solely on renewables relies heavily on technologies capable of converting electricity into chemicals and fuels suitable for heavy transport at high efficiencies. In addition, higher electrolysis efficiency and integrated fuel production can decrease the reliance on bioenergy further than conventional electrolysis.

\section{ADVANCES}

Electrolysis is the core in Power-to-X solutions (PtX), where X can be hydrogen, syngas or synthetic fuels. When electrolysis is combined with renewable electricity, the production of fuels and chemicals can be decoupled from fossil resources, paving the way for an energy system based on $100 \%$ renewable energy. Solid oxide electrolysis cell (SOEC) technology is attractive due to unrivaled conversion efficiencies - a result of favorable thermodynamics and kinetics at higher operating temperatures. SOECs can be used for direct electrochemical conversion of $\mathrm{H}_{2} \mathrm{O}, \mathrm{CO}_{2}$ or both into $\mathrm{H}_{2}, \mathrm{CO}$ or $\mathrm{H}_{2}+\mathrm{CO}$ (syngas), respectively. SOECs can be thermally integrated with a range of chemical syntheses, enabling recycling of captured $\mathrm{CO}_{2}$ and water into synthetic natural gas or gasoline, methanol or ammonia, resulting in further efficiency improvements compared to low-temperature electrolysis technologies. SOEC technology has undergone tremendous development and improvements over the past 10 to 15 years. The initial electrochemical performance of state-of-the-art SOEC single cells has more than doubled, while long-term durability has been improved by a factor of $\sim 100$. Similar 30 improvements in performance and durability have been achieved on stack-level. Furthermore, SOEC technology is based on scalable production methods and abundant raw materials such as nickel, zirconia and steel (no precious metals). Performance and durability improvements, as well as increased scale-up efforts have led to a hundred-fold gas production capacity increase within the last decade and to commissioning of the first industrially-relevant SOEC plants. The plant size is expected to further increase by a factor of almost 20 during the next 2 to 3 years. In recent years SOEC systems have been integrated with downstream synthesis processes: examples include a demonstration plant for upgrading of biogas to pipeline quality methane and the use of syngas $\left(\mathrm{CO}+\mathrm{H}_{2}\right)$ from an SOEC plant to produce fuels for transport via the Fischer-Tropsch process.

\section{OUTLOOK}

Improved understanding of the nanoscale processes occurring in SOECs will continue to result in performance and lifetime gains on cell-, stack- and system-level, which in turn will enable even larger and more efficient SOEC plants. In countries like Denmark and Germany, the share

45 of renewable electrical energy supply is now reaching 40 to $50 \%$. As this happens for a growing number of countries, demand for efficient large-scale energy conversion technologies such as SOEC is poised to increase. The increasing scale will help bring down production costs, thereby making SOECs cost-competitive with other electrolysis technologies and, through sufficient $\mathrm{CO}_{2}$ pricing, with fossil-based methods for producing $\mathrm{H}_{2}$ and CO. SOECs offer an 
opportunity to decrease the costs of future renewable energy systems with more efficient conversion, and synergies enabling further integration of renewable energy.

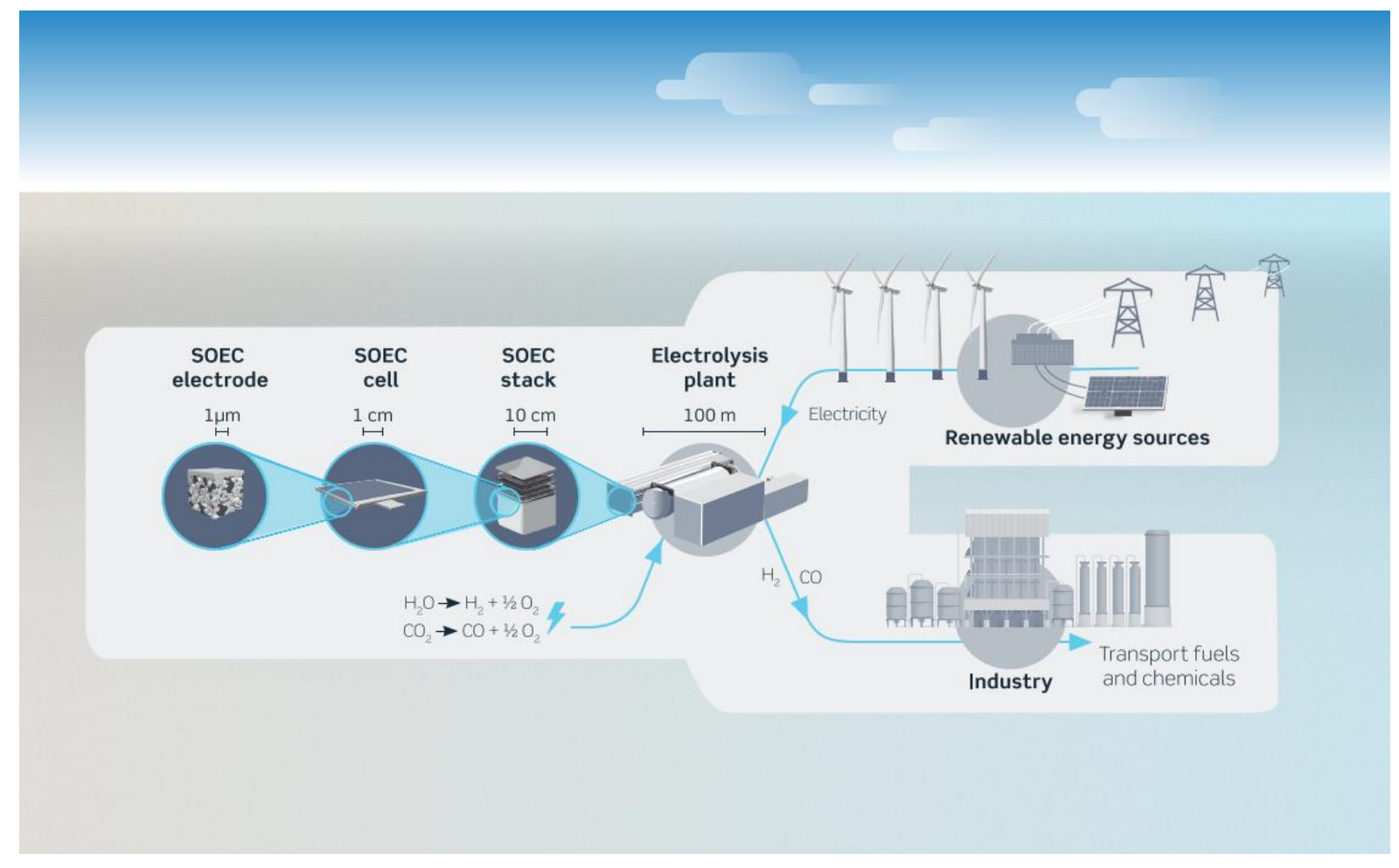

Figure

Solid oxide electrolyzers: from nano- to macroscale. The splitting of $\mathrm{H}_{2} \mathrm{O}$ or $\mathrm{CO}_{2}$ occurs at solid oxide electrolysis cell (SOEC) electrodes. Multiple cells are combined into SOEC stacks, which are in turn combined into SOEC plants. When renewable electricity is used, the production of transport fuels and chemicals can be decoupled from fossil resources. SOECs operate at elevated temperatures, resulting in electrolysis efficiencies unattainable by other electrolysis technologies. 
Our modern society relies heavily on fossil energy sources such as coal, natural gas and petroleum. The fossil fuels still serve as a vast and inexpensive source for on-demand heat and electricity, fueling every part of the economy from transportation to computing to heavy industry, but the share of renewables is steadily rising. However, a society based solely on lowcarbon energy sources is not only possible(1-3), but necessary to avoid the worst effects of climate change. Wind and solar could easily provide enough power to cover the global energy demand many times over (4), but the intermittent nature of these energy sources requires us to re-think and re-design our energy system.

First, technologies for storage and conversion of energy will have to be implemented at a massive scale to make seasonal energy storage possible. Second, the different branches of the energy system (electric grid, gas network, heat network, transportation sector) ) need to become much better integrated $(1,5)$, allowing temporary excesses in one branch to be synergistically absorbed by other branches. Third, though it is a good idea to electrify light-duty vehicles, synthetic fuels with their high energy density offer important advantages in the aviation, maritime and heavy-duty vehicle transport sectors. Fourth, the production of chemicals and commodities, such as steel, glass and cement, must be decoupled from the use of fossil resources.

The above challenges can be addressed by a "smart" energy system, such as the one depicted in Fig. 1. Here, electricity from renewable sources is used to power electrolysis plants capable of splitting water and carbon dioxide $\left(\mathrm{CO}_{2}\right)$. The resulting hydrogen $\left(\mathrm{H}_{2}\right)$ or carbon monoxide (CO) serve as feedstock for the chemical industry and fuel synthesis plants, thereby enabling various Power-to-X scenarios, where $\mathrm{X}$ stands for any chemical or fuel. The resulting green synthetic fuels can be used to power heavy or long-haul transport (planes, ships and trucks), while light-duty transport is powered by electricity stored in batteries. The heat demand of 25 buildings is preferably provided by district heating, e.g. by heat pumps or by excess heat generated by the industry.

Considering an energy system, as outlined in Fig. 1, obvious questions include: at what percentage of penetration of wind and solar in the electricity system will electrolysis be advantageous? How large a share of electricity demand can solar and wind cover? When will fluctuating renewable energy meet peak electricity demands, and how much of the time will an electrolysis plant actually be in operation? If we are to meet our need for storage of renewable energy, how many MW electrolysis plants and how many TWh of chemical storage will be needed? To answer and exemplify, studies show that beyond 40 to $50 \%$ penetration of wind power and photovoltaics in the electricity system, further sector integration in combination 35 with efficient energy conversion and storages technologies such as electrolysis is needed ( 1 , 5). European level analyses (as well as German and Danish scale studies) show that wind power and photovoltaics can cover 80 to $90 \%$ of the electricity demands in energy systems as sketched in Fig. $1(1-3,6,7)$. Fluctuating renewable energy will meet peak electricity demands at 40 to $50 \%$ penetration even with high electrification rates (3) and electrolysis can thereby 40 significantly increase the share of renewables using chemical storage while decarbonizing the transport sector. Though often left unmentioned, it should be noted that in the scenarios described above, due to the absence of cheap base load power, electrolysis plants need to be able to bear (both technologically and economically) dormancy at certain times. In some cases, the capacity factor for electrolysis plants may only be between 40 and $60 \%$. In general, GW

45 capacities installed on the production side need an aligned flexible demand. On a European scale, analyses show that $1600 \mathrm{GW}$ electrolysis and $7500 \mathrm{TWh}$ of chemical storage may be needed to completely de-carbonize heavy duty transport such as trucks, ships and planes (2). If this demand for energy storage were to be delivered from batteries, a capacity equivalent to batteries in approximately 50 billion Tesla Model 3's would be needed (roughly 160 times the number of cars in Europe today). Storage cost for chemical energy as hydrogen, methane in 
caverns, or liquids are today at the level of $<1 € / \mathrm{kWh}$ (excluding conversion costs), whereas the cost of battery storage is expected to remain significantly higher, reaching $80 € / \mathrm{kWh}$ by 2030 (8). Chemical liquid storage has much lower costs than battery storage but also lower cost than thermal and gaseous energy storage (8). Altogether, this analysis supports conversion of renewable electrical energy via electrolysis and storage of energy in liquid chemicals.

Electrolysis technologies will play a central role in future energy systems, acting as a vital link between the electric, gas, and thermal grids, as well as providing fuel for the transportation sector. The huge scale at which electrolysis needs to be deployed means that there is undoubtedly room for a wide range of electrolysis technologies, notably alkaline, polymerelectrolyte-membrane (PEM), and SOEC. We claim here that SOEC is the most suitable for wider-scale adoption. In the next sections, we will outline the inherent advantages of SOEC, including the higher conversion efficiencies, raw material availability, as well as potential synergies from integration with downstream chemical syntheses. We will further present an overview of the advances in performance and durability on cell and stack level that we have witnessed over the past 10-15 years. In books written on electrolysis technologies, it is common practice to focus on alkaline and PEM technologies, disregarding SOEC as an immature technology "still in R\&D phase" (9). The aim of this review is also to substantiate that via recent improvements, SOEC is now ready for industrial scale-up, and that the scale-up is in fact already happening at a rapid pace.

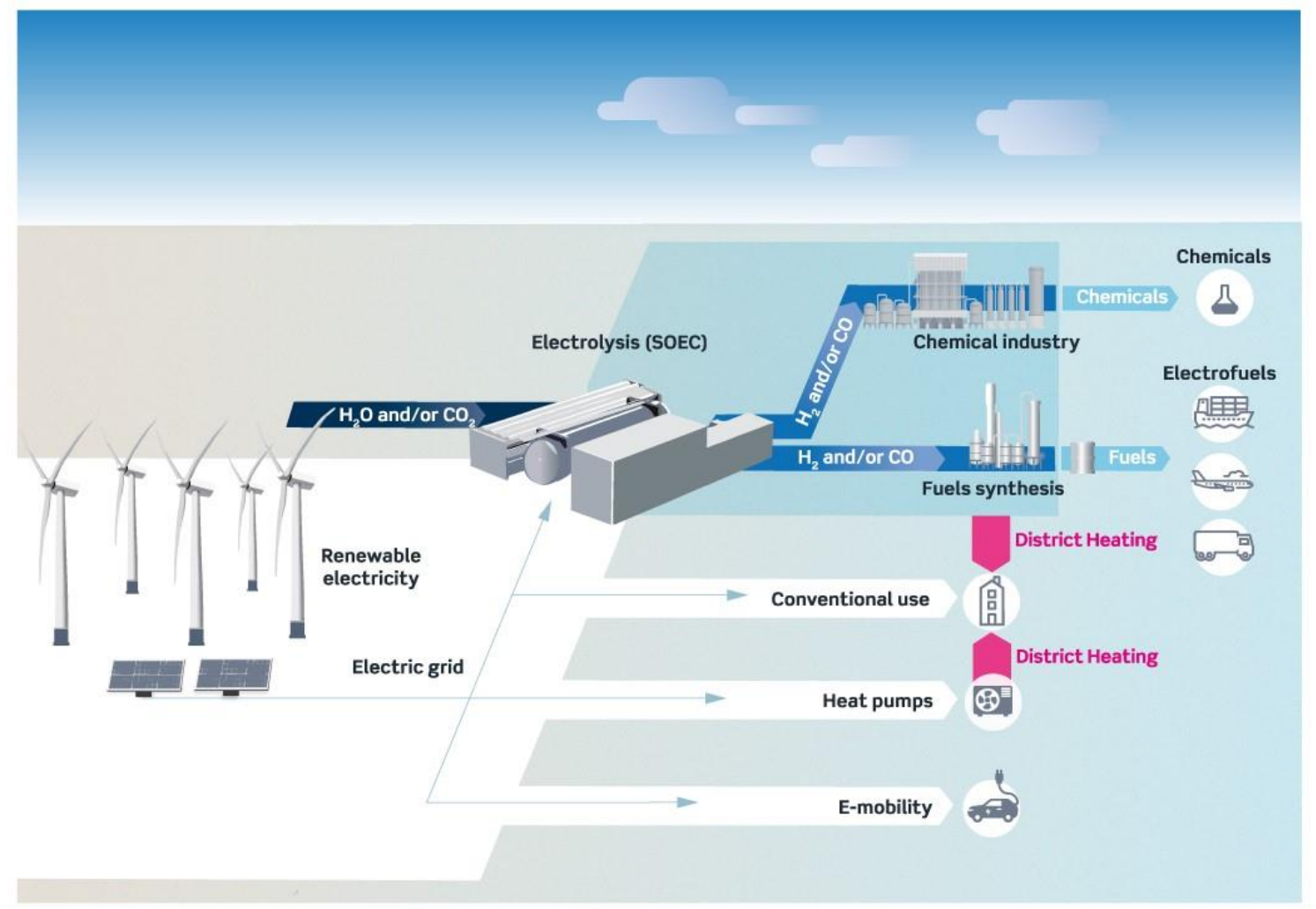

Fig. 1: Energy system based $100 \%$ on renewable energy. Illustration of the central role and integration of solid oxide electrolysis cells (SOECs) in a future energy system with increased share of intermittent electricity from renewable sources such as wind and solar. The different branches of the energy system (electricity, gas, thermal grids, transportation) are tightly coupled. 


\section{Unrivaled electrolysis efficiencies}

A solid oxide electrolysis cell consists of three main components: two porous electrodes and a dense ceramic electrolyte capable of conducting oxide ions $\left(\mathrm{O}^{2-}\right)$; see Fig. 2A, which is based on a scanning electron microscope (SEM) image of a planar ceramic-based fuel electrode supported cell. SOECs are capable of splitting water and $\mathrm{CO}_{2}$ into $\mathrm{H}_{2}$ and $\mathrm{CO}$, respectively, but can also be operated in co-electrolysis mode, converting a $\mathrm{H}_{2} \mathrm{O}-\mathrm{CO}_{2}$ mixture directly into synthesis gas $\left(\mathrm{CO}+\mathrm{H}_{2}\right)(10)$. Electrochemical reduction of $\mathrm{H}_{2} \mathrm{O}$ or $\mathrm{CO}_{2}$ proceeds on the negatively-charged fuel electrode, oxide ions are conducted through the electrolyte and onto the positively-charged oxygen electrode, where they oxidatively re-combine into gas-phase $\mathrm{O}_{2}$. When operated in reverse, an SOEC functions as a solid oxide fuel cell (SOFC). The cells may be operated reversibly, i.e. switching between SOEC and SOFC modes, depending e.g. on the spot electricity price (11). SOECs are available in a wide range of structural designs (electrolyte-supported, metal-supported, ceramic fuel electrode supported) and form factors (tubular, flat-tubular, planar), but the general characteristics of the technology remain the same regardless of the design. Multiple cells ( 30 to 100) are combined in series in an SOEC stack via metallic interconnects, which provide electrical contact and gas separation between the cells as well as gas distribution across the cells. Stacks are built into modules and assembled in systems to reach the desired gas production rate (see below).

Elevated temperatures are required to reach sufficient ionic conductivities. The most common ceramic electrolyte SOECs therefore typically operate at 600 to $850^{\circ} \mathrm{C}$ (12). The high operating temperature is an important feature of SOEC technology, giving rise to the two main advantages over competing alkaline and polymer-electrolyte membrane (PEM) electrolyzers typically operating at 60 to $160^{\circ} \mathrm{C}$ : i) more favorable thermodynamics and ii) faster kinetics. Theoretical thermodynamic efficiency for both $\mathrm{H}_{2} \mathrm{O}$ and $\mathrm{CO}_{2}$ electrolysis increases with increasing temperature. As the temperature is raised from $25^{\circ} \mathrm{C}$ to $800^{\circ} \mathrm{C}$, the theoretical voltage for splitting of $\mathrm{H}_{2} \mathrm{O}$ or $\mathrm{CO}_{2}$ falls by 20 to $30 \%$ (see details in (13)). In practice, when both thermodynamics and kinetics are considered, temperature-related efficiency gains are far higher: an SOEC operated at thermoneutral potential (1.29 V) for splitting of steam will attain an electrolysis current density of approximately $1.5 \mathrm{~A} / \mathrm{cm}^{2}$ whereas a PEM electrolyzer operated at thermoneutral potential $(1.47 \mathrm{~V})$ splitting liquid water attains a current density of $\sim 0.5 \mathrm{~A} / \mathrm{cm}^{2}$ at similar gas compositions (13). PEM electrolyzers are typically operated at higher potentials (1.6 to $1.7 \mathrm{~V}$ ), reaching current densities of $\sim 1 \mathrm{~A} / \mathrm{cm}^{2}(14-16)$. The difference in thermoneutral potentials is directly related to the heat of evaporation, $\Delta H_{\text {evap. }}$. High-temperature operation is even more beneficial in $\mathrm{CO}_{2}$ electrolysis mode as evident from Fig. 2C. Lower cell voltage translates directly into lower operational costs (lower electricity demand per quantity of produced gas), while higher current densities are associated with lower capital costs (fewer electrolyzers needed to achieve the required capacity for gas production). Hence, the economic motivation for wider adoption of SOEC technology remains high, provided the main challenges (performance degradation and scale-up) are successfully addressed as outlined in the subsequent paragraphs. 

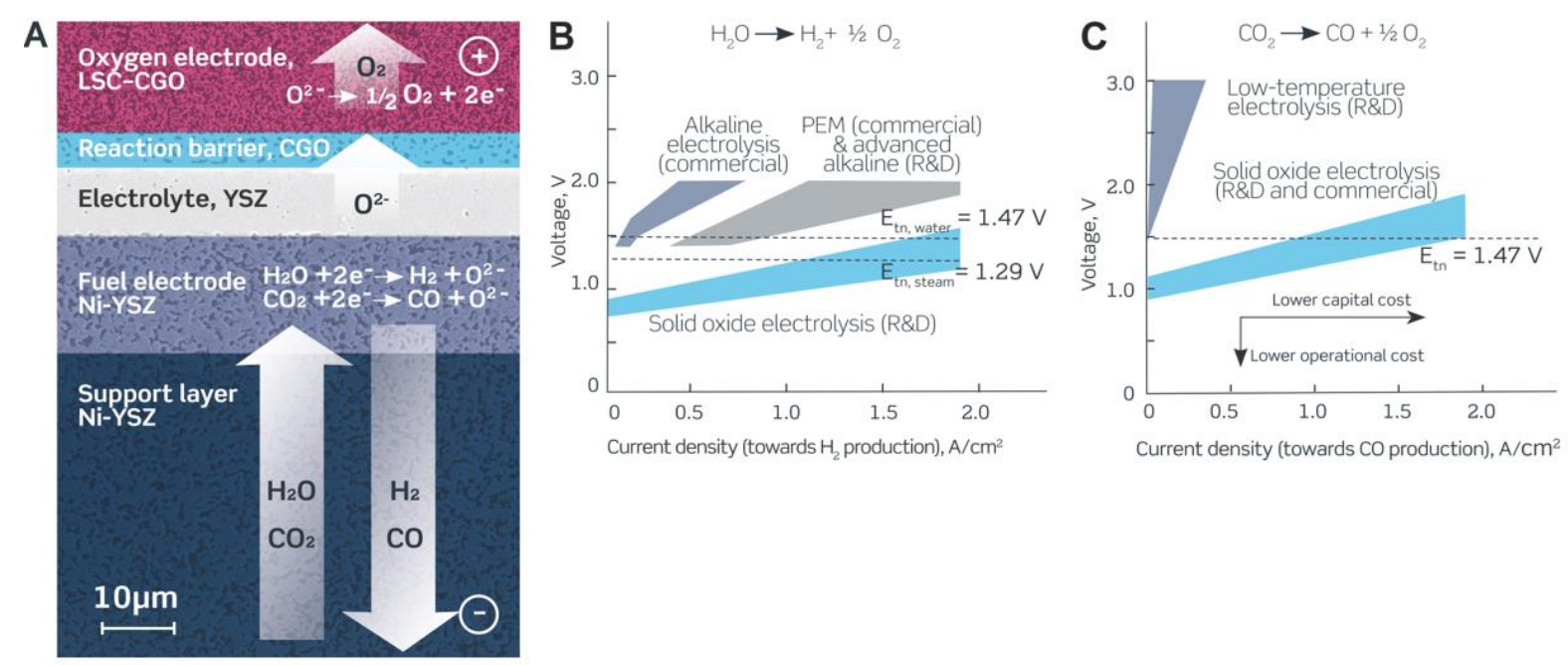

Fig. 2: Structure, operating principle and performance of SOEC: (A) Electron microscopy (color overlaid) image of the active layers of SOEC and the electrochemical reactions occurring in the cell during $\mathrm{H}_{2} \mathrm{O}$ and $\mathrm{CO}_{2}$ electrolysis. Typical performance ranges

for competing electrolysis technologies for $(\mathbf{B}) \mathrm{H}_{2} \mathrm{O}$ splitting, (C) $\mathrm{CO}_{2}$ splitting. A is modified after (11) with permission from Oxford University Press, $\mathbf{B}$ is adapted and modified from (17) with permission from Elsevier and $\mathbf{C}$ from open access (18).

\section{Technology based on abundant raw materials}

The scale at which electrolysis cells will have to be deployed in future energy scenarios requires any viable electrolysis technology to be based on Earth-abundant materials, which is the case for the commonly used SOEC materials. In most cell designs, the majority of the cell comprises either yttria-stabilized zirconia (YSZ) - for electrolyte-supported cells - or a composite of metallic Ni and YSZ for fuel electrode supported cells (Fig. 2A). YSZ, a solid solution of few mole-\% yttria $\left(\mathrm{Y}_{2} \mathrm{O}_{3}\right)$ in zirconia $\left(\mathrm{ZrO}_{2}\right)$, remains the electrolyte material of choice. Both yttria and zirconia are abundant materials: solid oxide cells providing $1 \mathrm{TW}$ of power in fuel cell mode would require just 1 month's worth of global $\mathrm{ZrO}_{2}$ production and 21 months' worth of $\mathrm{Y}_{2} \mathrm{O}_{3}$ (19). To put these numbers into perspective: 24 hours of $1 \mathrm{TW}$ of power generated using

20 Li-ion batteries would require Li corresponding to 160 years of Li production in 2012 and a 1 TW of power provided by a PEM fuel cell system would require 53 months' worth of global Pt production (19). A similar back-of-the-envelope calculation suggests that availability of Ir will be a concern. For a single low-temperature $500 \mathrm{MW} \mathrm{CO}_{2}$ electrolysis plant, envisioned by De Luna et al. in (20) would, at $\mathrm{IrO}_{2}$ loadings used in (21), need roughly $2 / 3$ of the global annual production of Ir (19). The SOEC fuel electrode relies on catalysis by $\mathrm{Ni}$, a non-noble metal with a flexible supply. For less demanding applications, oxygen electrodes based on abundant Sr-doped $\mathrm{LaMnO}_{3}$ (LSM) may be used, while higher-performing applications require electrodes based on mixed conductors, such as lanthanum-strontium-ferrite-cobaltite (LSCF) or lanthanum-strontium-cobaltite (LSC) (22). Thin (0.1-5 $\mu \mathrm{m})$ layers of gadolinia-doped ceria 30 (CGO) are commonly used to prevent reaction between oxygen electrode materials and YSZ (23). 


\section{Advances on cell-level}

\section{Initial performance}

Current-voltage curves recorded in steam electrolysis reveal that the initial performance of SOECs has increased by more than a factor of 2.5 over the past 15 years (Fig. 3A), evidenced by a drop in area-specific resistance from $0.71 \Omega \mathrm{cm}^{2}$ to $0.27 \Omega \mathrm{cm}^{2}$ at $750^{\circ} \mathrm{C}(24,25)$. Although recent data are not readily available for $\mathrm{CO}_{2}$ electrolysis, literature results suggest cells optimized for $\mathrm{H}_{2} \mathrm{O}$ electrolysis generally perform almost as well in $\mathrm{CO}_{2}$ electrolysis (26). The performance enhancements shown in Fig. 3A have been achieved through three main modifications: i) improved processing of cell layers, especially the fuel electrode, ii) switching

10 from LSM to mixed conducting oxides (LSCF, LSC) in oxygen electrode, and iii) increasing the surface area of electrochemically active phases, e.g. by infiltration, atomic layer deposition or pulsed laser deposition.

\section{Improved processing}

15 Cell fabrication has witnessed multiple small breakthroughs during the past 15 years for both porous electrodes and the dense gas-tight electrolyte. Large shares of the performance increase illustrated in Fig. 3 are due to enhanced performance of the fuel electrode. However, the largest individual contributions to the cell resistance still originate from the charge transfer reaction at the triple phase boundaries (TPBs) in the fuel electrode. At the TPB, the electron-conducting

20 and electro-catalytically active $\mathrm{Ni}$, the gas-conducting pore, and the oxide-ion conducting YSZ are adjacent to each other. Advances in imaging techniques have made it possible to quantify the concentration and 3D distribution of TPBs in real electrodes (27-30) enabling further improvements in electrode performance (31).

Methods for applying orders-of-magnitude thinner electrolytes, i.e. in the sub-micrometer range (23) and the development of alternative ionic conductors (such as doped ceria or zirconia with new or multiple dopants) demonstrates that research in electrolyte materials - a field $\sim 100$ years old - can still unlock improved performance $(12,32,33)$. Improved processing methods have enhanced the mechanical properties (Weibull strength and fracture toughness) of SOECs $(34,35)$, allowing the thickness of the Ni-YSZ support layers to be reduced from the typical 0.5 to $1 \mathrm{~mm} \mathrm{(36)}$ to 0.3 to $0.6 \mathrm{~mm} \mathrm{(37),} \mathrm{resulting} \mathrm{in} \mathrm{major} \mathrm{cost} \mathrm{reductions} \mathrm{on} \mathrm{cell-level.}$ Recently, an SOEC stack was flight-qualified for a mission to Mars (38), demonstrating that brittle ceramic cells, when properly encapsulated, can withstand very challenging mechanical load scenarios.

\section{Mixed ionic electronic conducting oxides as oxygen electrode material}

The second reason for performance enhancements is related to the introduction of mixed ionic and electronic conductors (MIEC) as electro-catalytic material on the oxygen electrode. In composites of pure ion conductors (e.g. YSZ) and pure electronic conductors (e.g. LSM), the electrochemistry is limited to the TPB sites, i.e. to interfaces where the gas-phase is simultaneously in contact with both solid phases. By replacing the electronic conductor with a MIEC material (e.g. LSCF), the reaction zone extends onto the MIEC phase, drastically increasing the number of electrochemically active sites in the oxygen electrode (39). MIEC generally also improves reaction kinetics. 


\section{Increased reaction zone via nano-engineering of electrode structures}

A variety of methods can be applied to manufacture nano-engineered electrode structures e.g. infiltration, atomic layer deposition (ALD), pulsed layer deposition (PLD), exsolution etc. (4043). Applying infiltrated nano-sized electro-catalysts into a Ni-YSZ electrode structure shrinks the catalytic particles from micro-meter scale to the nano-meter scale, and dramatically increases TPB lengths, thereby enhancing electrode performance. Compared to a standard electrode, electrodes with increased number of active sites per electrode volume will inevitably be able to operate at lower overpotential for the same given externally set current density. Furthermore, nano-particle infiltrated Ni-YSZ electrodes have shown to be stable for hundreds

10 of hours at high current densities (40).

\section{Durability}

Improvements in initial performance have been accompanied by tremendous advances in durability. Fig. 3B shows two cell tests conducted at an electrolysis current of $1 \mathrm{~A} / \mathrm{cm}^{2}$. The 15 resulting degradation rate, commonly expressed as voltage increase over 1000 hours, has decreased by a factor of 100 and is now below $0.5 \% \mathrm{~V} / 1000 \mathrm{~h}$ (44). Similar low degradation rates have recently been reported in cells operated at $1 \mathrm{~A} / \mathrm{cm}^{2}$ and lower temperatures $\left(750^{\circ} \mathrm{C}\right)$ (40). Generally, cell degradation rates tend to decrease over time (Fig. 3B), a trend that has remained valid even in tests approaching three years (45). From the increasing portfolio of SOEC long-term tests, two main insights with respect to degradation causes have emerged: i) the effect of impurities and ii) the close link between initial performance and resulting degradation rate.

It is the fuel electrode that is the primary source of degradation for the majority of long-term tests reported. Several studies have shown that silica-containing impurities (glass phases) can block the electrocatalytically active sites as illustrated in the transmission electron micrograph in Fig. 3C. Such blocking of the TPB sites by non-conducting phases will inevitably cause degradation and lead to increased polarization resistance. Likewise, sulfur-containing impurities have been found to be critical in $\mathrm{CO}_{2}$ and co-electrolysis experiments (46). For $\mathrm{CO}_{2}$ and co-electrolysis, not only the thermodynamic threshold for carbon deposition, but also the interplay between impurities (causing a higher fuel electrode overpotential) and the carbon deposition threshold play a role, as outlined in previous work (47); recent studies show positive effects of mixing of doped ceria and stabilized zirconia as oxide ion conducting material (48). The lesson learned from several long-term tests and impurity-related degradation causes is that

35 cleaning of inlet gases is a beneficial lifetime-prolonging investment for SOEC, and gas purification can be - and is being - integrated in cell test as well as for demonstration plants (46).

Improved initial performance for the oxygen electrodes based on the MIEC electrocatalysts (e.g. LSC and LSCF) also positively affects the long-term durability. At higher current densities, lower-performing LSM-YSZ composite electrodes cause a higher $\mathrm{pO}_{2}$ gradient in the YSZ electrolyte, prompting $\mathrm{O}_{2}$ bubble formation in the electrolyte close to the oxygen electrode which in turn leads to decreased $\mathrm{O}^{2-}$ conductivity and an irreversible increase in ohmic resistance of the cell (49). Even though state-of-the-art LSCF and LSC based oxygen electrodes contribute only $\sim 5$ to $10 \%$ of the total resistance of the cell and limited degradation is observed

$45(22,25,31)$, recent model electrode studies show that future oxygen electrode development efforts should be targeted towards designing and controlling both microstructure and especially 
surfaces (chemical compositions and valence states) as they significantly influence the electrochemical performance (50-52).

For the fuel electrode there is also a link between initial performance and the resulting degradation rate (31). Several studies have shown that in long-term operation at high fuel electrode overpotentials $(\sim 300 \mathrm{mV})$, the percolating $\mathrm{Ni}$ network closest to the electrolyte is destroyed and $\mathrm{Ni}$ migrates from the electrolyte-electrode boundary to the support layer, resulting in irreversible loss of electrochemical performance $(31,53)$. Similar studies of loss of the percolating Ni network were reported in 3D reconstruction studies (54). Notice that the $\mathrm{Ni}$ migration is observed for SOEC operation of the cells, but not seen to the same extent in cells tested in fuel cell mode with similar externally set test conditions, thus clearly pointing towards the local $\mathrm{pO}_{2}$ in the fuel electrode being the critical parameter (55). For future improvements of the SOEC this observed irreversible degradation due to Ni migration needs to be tackled.
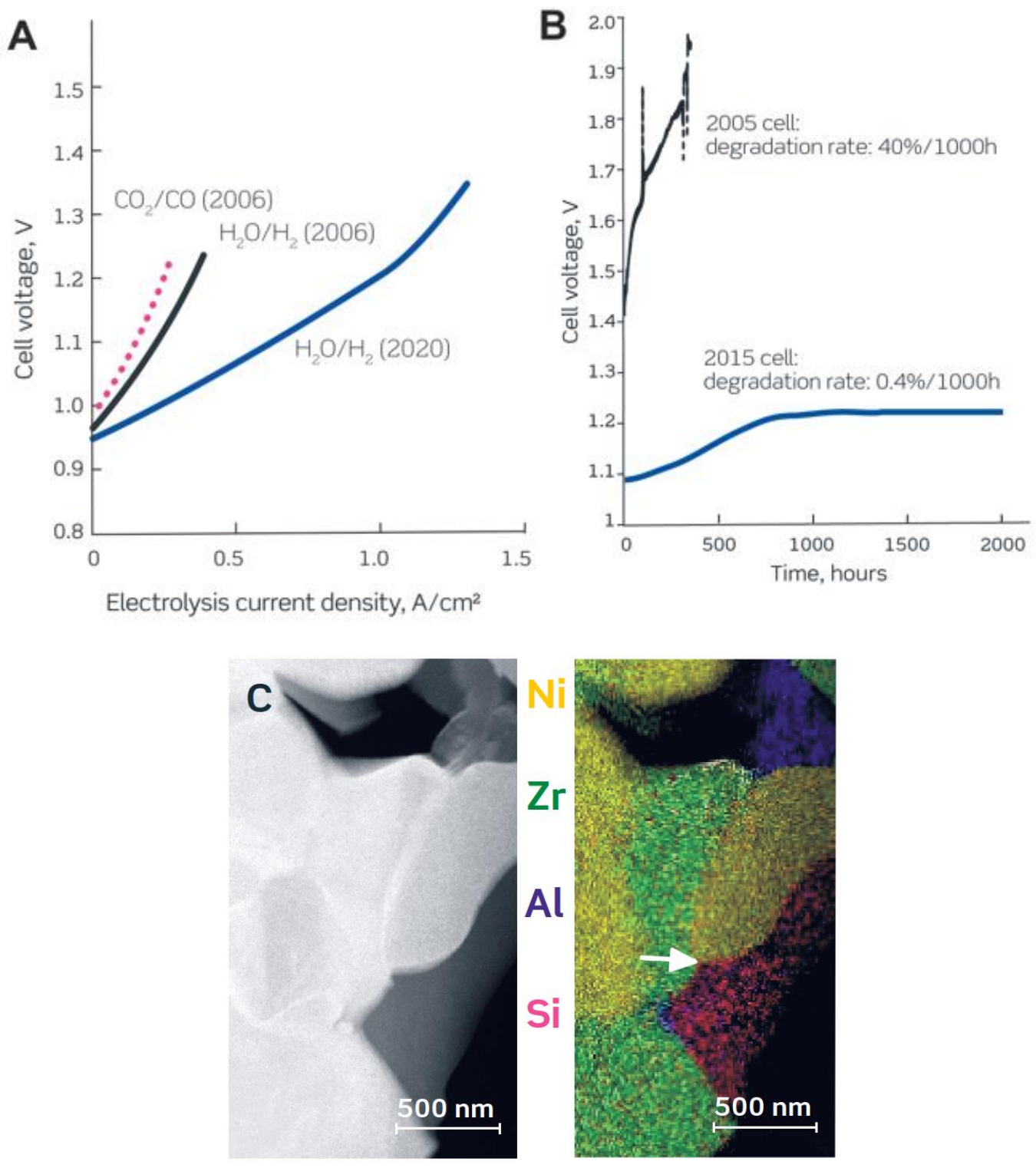

Fig. 3: Improvements on cell level. (A) Current-voltage curves for cells fabricated in 2006 and 2020 with data from $(24,25,56)$ at $750^{\circ} \mathrm{C}$, measured in $\mathrm{H}_{2} \mathrm{O} / \mathrm{H}_{2}=1$ or $\mathrm{CO}_{2} / \mathrm{CO}=1$. (B) 
Durability test of $\mathrm{H}_{2} \mathrm{O}$ electrolysis at $1 \mathrm{~A} / \mathrm{cm}^{2}$ by a cell fabricated in 2005 measured at $850^{\circ} \mathrm{C}$ and a cell fabricated in 2015 measured at $800^{\circ} \mathrm{C}(44)$. All cells were supported by a Ni-YSZ electrode and had an active area of $16 \mathrm{~cm}^{2}$. (C) TEM of Ni-YSZ electrode and corresponding energy dispersive $\mathrm{x}$-ray mapping illustrating the presence of a Si-Al glass phase at the TPB

(57). Figure (C) adapted with permission from Electrochemical Society.

\section{Improvements on stack-level}

\section{Durability}

A single $100 \mathrm{~cm}^{2}$ solid oxide electrolysis cell operating at $0.8 \mathrm{~A} / \mathrm{cm}^{2}$ produces approximately 30 liters of gas $\left(\mathrm{H}_{2}, \mathrm{CO}\right)$ per hour. In order to increase the output capacity, electrolysis cells are connected in series and assembled together into stacks. Such stacks typically contain between 30 and 100 cells, translating into a production rate of 1 to $3 \mathrm{Nm}^{3}$ of gas (90 to $270 \mathrm{~g} \mathrm{H}_{2}$ ) per hour. Here, $\mathrm{Nm}^{3}$ refers to cubic meters of gas under normal conditions $\left(0^{\circ} \mathrm{C}, 1 \mathrm{~atm}\right)$. The electrochemical performance of SOEC stacks is determined not only by the activity of the cells, but also by the performance of other stack components: metallic interconnects, glass sealings, flow channels. The properties of each of these components change during long-term operation (interconnects corrode and creep, glass crystallizes, electrodes coarsen and accumulate impurities, elements inter-diffuse), and the components strongly interact; hence improvements demonstrated on single component level do not necessarily lead to enhanced performance on stack-level. However, also here substantial progress has been made, evidenced by the gradually increasing test time reported in the literature (Fig. 4A) and by the corresponding drop in degradation rates (Fig. 4B). In 2011, the longest reported stack test in steam electrolysis lasted for less than 6 months, whereas now, stack lifetimes approaching 2.5 years have been experimentally demonstrated (45). It is only within the last $\sim 5$ years that tests exceeding 1000 hours have been reported for $\mathrm{CO}_{2}$ and co-electrolysis, but the durability gap between different electrolysis modes is closing fast, as more tests are performed with $\mathrm{CO}_{2}$. Test times exceeding a year in dry $\mathrm{CO}_{2}$ electrolysis mode suggest that SOEC is today by far the most mature technology for direct electrochemical conversion of $\mathrm{CO}_{2}$ into $\mathrm{CO}$ (18).

State-of-the-art SOEC stacks are not only less prone to hard failures (sudden losses in

30 performance) but - in line with cell-level results - the stacks also degrade less rapidly than a decade ago (Fig. 4B). For most reported tests, degradation rates now remain below $1 \%$ per 1000 hours, regardless of whether the stacks are operated in steam, $\mathrm{CO}_{2}$ or in co-electrolysis mode. Encouragingly, stacks using similar cells and stack components have been operated continuously in fuel cell mode for more than 11 years (36) and over 50000 residential SOFC units have already been installed in Japan (58). 

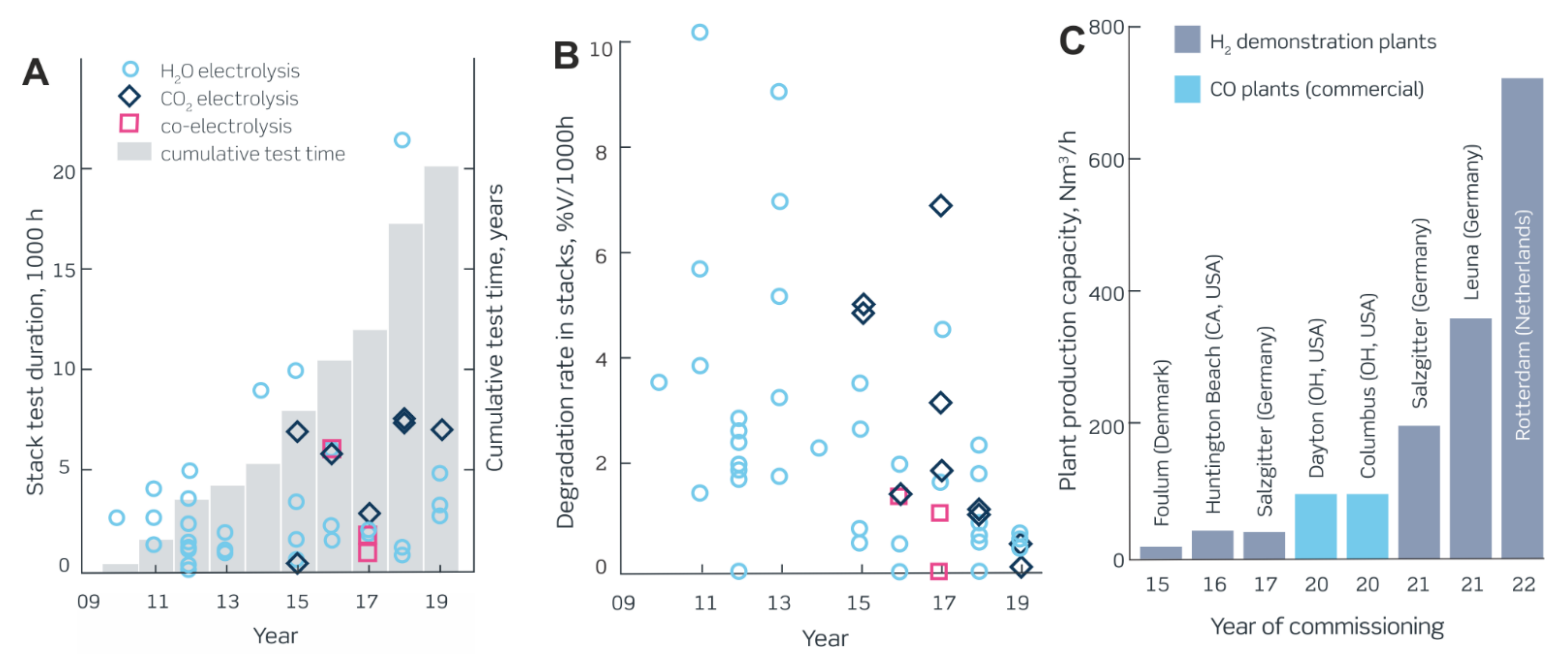

Fig. 4: Stack durability improvements and scale-up. Development over time of (A) reported stack test duration since 2009, (B) the corresponding degradation rates and (C) SOEC plant production capacities from 2015. Data in $(\mathbf{A})$ and $(\mathbf{B})$ are based on $(59,60)$ and data in $(\mathbf{C})$ from $(61)$.

\section{Robustness}

A robust and flexible energy conversion technology is required to cope with the wide range of operating conditions in future energy scenarios. Historically, SOEC technology has struggled to demonstrate tolerance towards e.g. thermal (cool-down/heat-up) and emergency shutdown cycles, but this has recently changed. Stacks based on ceramic-supported cells can now withstand approximately 150 thermal cycles (62) while stacks based on metal-supported cells have been shown to endure more than 2500 such cycles (63). In fact, SOEC technology has matured to a point where the unreliability of system components (compressors, heaters, power supplies) other than the stack, or simply power failures, have become the main cause for system shutdowns $(33,64)$. Still, certain misconceptions prevail: first, that the brittleness of ceramic cells makes them unsuitable for pressurized operation and second, that SOEC cannot follow dynamic load, e.g. the intermittent electricity output from renewable energy sources. Both claims have been disproven by recent results, as outlined below.

20 Pressurized SOEC stack operation has been reported at pressures up to 25 bar $(65,66)$. Due to improved kinetics and diffusion rates, the performance of SOECs typically improves slightly with pressure. Stable operation at high pressures can successfully be maintained, as long as the pressure difference between the fuel- and air-side compartments of the cell is minimized. Highpressure operation enables closer integration between electrolyzers and pressurized chemical

With respect to dynamic load operation, it has been shown that stacks at operating temperature can be ramped from zero to $80 \%$ load in a matter of milliseconds without damage (33); in a different study, an 8-cell stack was operated to follow a wind-profile for 1200 hours with the current load modified every 5 minutes without additional degradation (11). Similar tests have 30 since then been performed using commercially available stacks (67), in co-electrolysis (68) as well as on single-cell (69) and system-level (33). In large electrolysis plants as sketched in Fig. 1 , stack-level load following may not be necessary; the modular structure of such plants allows production rate to be adjusted incrementally by turning stack modules on or off. 


\section{The path to scale-up}

The production capacity of an SOEC plant is directly proportional to the overall active area of the electrolysis stacks, as well as the applied current density. State-of-the-art SOEC stacks often have cell footprints (active electrode area) in the range of $\sim 100 \mathrm{~cm}^{2}$; however cells with footprints as high as $550 \mathrm{~cm}^{2}$ have been successfully produced and demonstrated (37). SOEC stacks with 100 or more cells are becoming commonplace and designs for stacks with 350 cells have been proposed (37). Current densities as high as $3 \mathrm{~A} / \mathrm{cm}^{2}$ have been reported on stacklevel using cells based on conventional SOEC materials (i.e. no noble metals), simply by optimizing the electrode microstructure and test conditions (37). A stack combining all of the listed improvements $\left(550 \mathrm{~cm}^{2}, 3 \mathrm{~A} / \mathrm{cm}^{2}, 350\right.$ cells/stack) would boast a production capacity of $240 \mathrm{Nm}^{3} / \mathrm{h}$ of gas $\left(21.6 \mathrm{~kg} \mathrm{H}_{2} / \mathrm{h}\right)$, i.e. a factor of 80 to 240 higher than today's stacks. Though currently hypothetical, there are no fundamental obstacles preventing such stacks from being built.

Fig. 4C illustrates the evolution of SOEC plant sizes measured in gas production capacity from 2015 to 2022, showing only plants for which funding has been allocated. As of early 2020, the largest operating SOEC demonstration plant is located in Salzgitter, Germany and has a capacity of $40 \mathrm{Nm}^{3} \mathrm{H}_{2} / \mathrm{h}$. The plant consists of six modules of 48 stacks, each with 30 cells (33). However, demonstration plants with capacities reaching $720 \mathrm{Nm}^{3} / \mathrm{h} \mathrm{H}_{2}$ (70) and multiple commercial (i.e. subsidy-free) plants with capacities of $96 \mathrm{Nm}^{3} / \mathrm{h} \mathrm{CO}(71)$ are to be commissioned in the next two years (Fig. 4C). Considering that the $\mathrm{H}_{2}$ demand for a single methanol plant is on the order of $10000 \mathrm{Nm}^{3} / \mathrm{h}$, it can be envisaged that SOEC systems can reach the required scale within a decade.

\section{Outlook - from nano- to industrial scale}

\section{Synergies and integration of SOEC with chemical synthesis}

From an overall efficiency point of view, electrolysis systems should be operated close to thermoneutral potential ( $1.29 \mathrm{~V}$ and $1.47 \mathrm{~V}$ for steam and $\mathrm{CO}_{2}$, respectively) i.e. the potential at which the cooling effect from the endothermic electrolysis process is balanced by the Joule heating caused by the resistances in the cell (see (13)), which in turn means that higher current

30 density operation, i.e. higher $\mathrm{H}_{2}$ and/or CO production rate, is possible for SOEC (Fig. 2B and C) especially in the case of $\mathrm{CO}_{2}$ electrolysis.

For the integration of SOEC in a future energy system as sketched in Fig. 1, significant synergies can be obtained if the SOEC plant is integrated with downstream syntheses e.g. production of chemicals and fuels like methane, methanol, gasoline, diesel, jet fuel and ammonia $(72,73)$. Fig. 5 illustrates integration of SOEC with synthesis of methane, methanol and ammonia and the beneficial use of heat from the synthesis processes, which are exothermic. The heat released can be used to produce the steam needed as feedstock for the SOEC. Notice in Fig. 5C that for coupling with ammonia synthesis, the unique capability of SOEC as an effective oxygen separation membrane is taken advantage of; the use of heat in lieu of power

40 can be harnessed to eliminate the need for the expensive air separation unit to provide the nitrogen. Balance of plant details for the three scenarios sketched in Fig. 5 are given elsewhere (74). Recent demonstration projects with integration of SOEC systems with downstream synthesis processes are promising, e.g. for upgrading of biogas to pipeline quality biomethane in a pilot plant providing $10 \mathrm{Nm}^{3} / \mathrm{h}(75)$. Here, a constant production was maintained for more than 2000 hours with electric power consumption for the SOEC of $3.07 \mathrm{kWh} / \mathrm{Nm}^{3} \mathrm{H}_{2}$ and the overall exergy efficiency from DC power to extra methane was close to $80 \%$ (76). Similarly, results on a $200 \mathrm{~kW}_{\mathrm{AC}}\left(50 \mathrm{Nm}^{3} / \mathrm{h} \mathrm{H}_{2}\right) \mathrm{SOEC}$ system as well as a pressurized system $\left(10 \mathrm{~kW}_{\mathrm{AC}}\right)$ to be integrated with a methanation unit have been reported recently (33). 

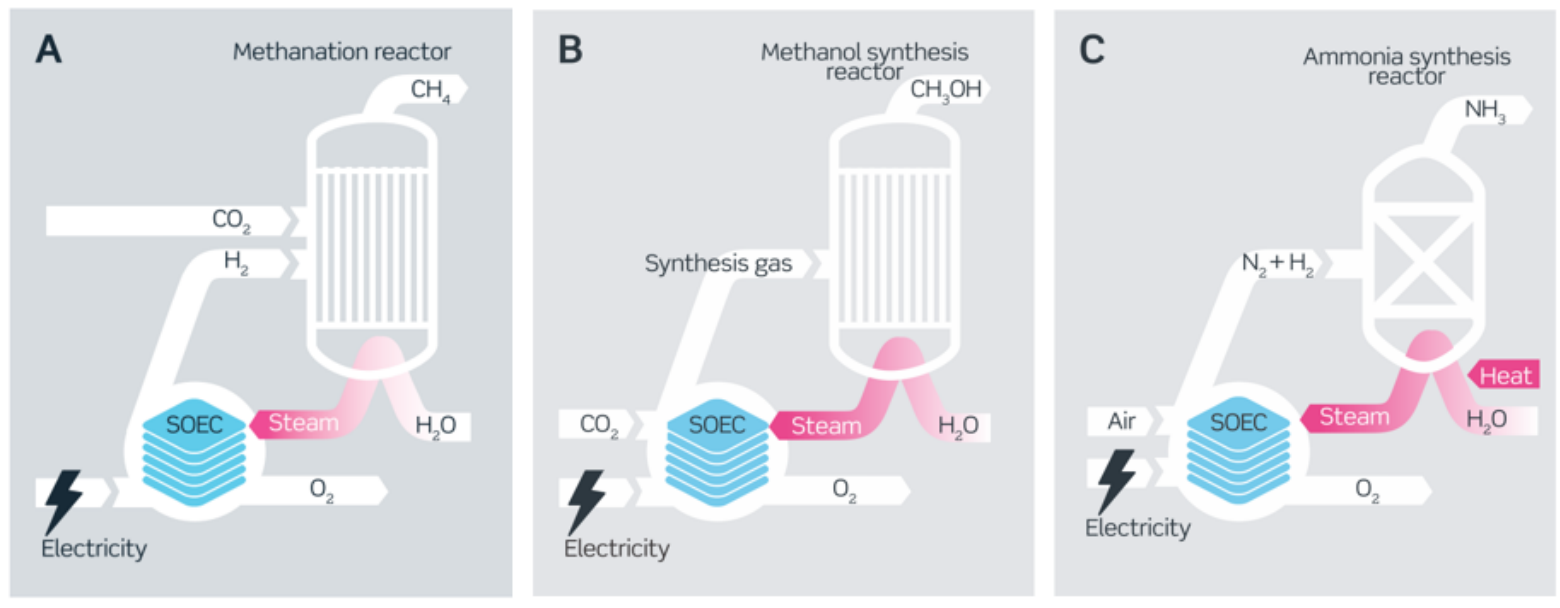

Fig. 5. Integration of SOEC with chemical syntheses. When SOEC is combined with a synthesis process, such as (A) methanation, (B) methanol synthesis, or (C) ammonia synthesis, reaction heat can be used to generate steam for SOEC. In (C), SOEC also functions as an oxygen-separation membrane, obviating the need for cryogenic air separation (73).

\section{Price competitiveness of SOEC}

According to literature estimates, a 5 MW SOEC system is currently available at a cost (CAPEX) of roughly $2,000 € / \mathrm{kW}$, while the cost is projected to approach $1,000 € / \mathrm{kW}$ by 2030 and reach $530 € / \mathrm{kW}$ by 2050 , based solely on cost reductions due to economies of scale (77). The operational cost (OPEX) will eventually be the main determining factor for choosing electrolysis technology. Studies have shown that electricity cost will be the major contributor (>70\% in some cases) to OPEX in future electrified chemicals and synthetic fuel production plants based on electrolysis (78). However, at the end of the day what the consumer will ask is: "what is the price of my synthetic gasoline?" A recent technoeconomic assessment of 20 Power-to-gasoline reached a gasoline price of $2.25 € /$ liter with several cost and efficiency assumptions including a price of electric power of $81.6 € / \mathrm{MWh}(79)$. Likewise, a targeted price of less than $2 € /$ liter was announced for a demonstration project with a capacity of producing 8000 tons of liquid fuel per year $(80)$.

Future R\&D - on cell, stack and system level

In this review, we have highlighted some of the key developments in SOEC technology during the past 10 to 15 years. The technology has moved from R\&D phase into demonstration and scale-up phase and is on the verge of commercialization. Nevertheless, R\&D on SOEC has not stopped and further performance enhancements, likely just as large as have been presented here, are possible on cell-, stack-, and system-level.

On a cell level the initial performance has increased a factor of $\sim 2.5$ and the degradation rate has been decreased a factor $\sim 100$ over the last 15 years. If there were only funding for $R \& D$ for one single part of the cell then it would be best spent on developing an even more robust and long-term stable fuel electrode. Projecting the next years of R\&D on the fuel electrode, the core task will be to develop a robust electrode structure preventing Ni migration and ideally an impurity-tolerant electrode for which carbon deposition can be avoided; however the issue of carbon deposition and impurity-induced degradation can to a large extent be avoided by 
purification of gas feedstock and proper choice of operating conditions on system level, leaving $\mathrm{Ni}$ migration as the key issue to resolve. Work already initiated and referenced above on nanostructuring as well as examples of additions of dopant(s) to anchor Ni particles are promising (81). Furthermore, electrodes designed by exsolution in perovskite-structured titanates (e.g. La-Co-Ni-Ti oxides or La-Sr-Ti oxides with in-situ exsolution of $\mathrm{Mn}, \mathrm{Cr}$ and/or $\mathrm{Ni}$ oxide nanoparticles) could be future viable routes to mitigate $\mathrm{Ni}$ migration and produce carbontolerant electrodes $(82,83)$. Likewise, fuel electrodes based on nano-infiltrated or exsolved nanoparticulate doped $\mathrm{Sr}-\mathrm{Fe}-\mathrm{Mo}$ oxides could be alternative substitutes for the commonly used Ni-YSZ $(42,84)$.

10 On stack level, improving durability and reducing cost have served as the mantra for the solid oxide community ever since the first such electrolyzers were demonstrated in 1980s (85). Going forward, the performance metric to be maximized should not be durability (expressed in hours), but the amount of gas produced over the stack's lifetime (86). This way, stacks operated at very different conditions (low or high current, dynamic or constant operation) could be compared. SOEC will not become the electrolysis technology of choice unless the total cost of ownership (cost of $1 \mathrm{~kg} \mathrm{H}_{2}$ ) is brought down to a lower level than achievable by alkaline or PEM electrolyzers.

On balance-of-plant/system level, reliability of components other than the stack remains a challenge. As noted above, stack failures rarely initiate system shutdowns (33). Therefore attention needs to be given to adapting and maturing balance-of-plant components for SOEC systems.

Acknowledgments: The authors acknowledge colleagues at Dept. of Energy Conversion and Storage, Technical University of Denmark and Haldor Topsoe for valuable discussions.

25 Funding: This work was partly funded by the Innovation Fund Denmark (IFD) under File No. 9067-00036B REFORGE; Competing interests: R.K. and P.B. own employee shares of Haldor Topsoe A/S. R.K., P.B. and J.B.H. are involved in the development and commercialization of SOEC-based electrolyzers and are (co-)inventors of several relevant patent applications assigned to Haldor Topsoe A/S.

\section{References}

1. B. V. Mathiesen, H. Lund, D. Connolly, H. Wenzel, P. A. Østergaard, B. Møller, S. Nielsen, I. Ridjan, P. Karnøe, K. Sperling, F. K. Hvelplund, Smart Energy Systems for coherent $100 \%$ renewable energy and transport solutions. Appl. Energy. 145, 139-154 (2015).

2. D. Connolly, H. Lund, B. V. Mathiesen, Smart Energy Europe: The technical and economic impact of one potential 100\% renewable energy scenario for the European Union. Renew. Sustain. Energy Rev. 60, 1634-1653 (2016).

40 3. K. Hansen, B. V. Mathiesen, I. R. Skov, Full energy system transition towards $100 \%$ renewable energy in Germany in 2050. Renew. Sustain. Energy Rev. 102, 1-13 (2019).

4. R. Perez, M. Perez, A fundamental look at energy reserves for the planet (2009), (available at http://asrc.albany.edu/people/faculty/perez/Kit/pdf/a-fundamental-look-at the-planetary-energy-reserves.pdf, accessed July $17^{\text {th }} 2020$ ).

45 5. B. V. Mathiesen, H. Lund, Comparative analyses of seven technologies to facilitate the integration of fluctuating renewable energy sources. IET Renew. Power Gener. 3, 190204 (2009).

6. H. S. Edlefsen, A. B. Hansen, C. Vittrup, "System Perspective 2035. March 2018: 
Long-term perspectives for efficient use of renewable energy in the Danish energy system" (available at https://en.energinet.dk/systemperspective2035, accessed July $17^{\text {th }}$ 2020).

7. B. V. Mathiesen, H. Lund, K. Hansen, I. Ridjan, S. R. Djørup, S. Nielsen, P. Sorknæs, J. Z. Thellufsen, L. Grundahl, R. S. Lund, D. Drysdale, Dave; D. Connolly, P. A. Østergaard, IDA's Energy Vision 2050 A Smart Energy System strategy for 100\% renewable Denmark (2015) (available at https://vbn.aau.dk/files/222230514/Main_Report_IDA, accessed July $17^{\text {th }} 2020$ ).

8. H. Lund, Energy storage and smart energy systems. Int. J. Sustain. Energy Plan.

Manag. 11 (2016), 3-4. dx.doi.org/10.5278/ijsepm.2016.11.2

9. A. Smith, A. S. Pedersen, Electrolysis. Encycl. Environ. Manag. (2014), doi:10.1081/e-eem-120050577.

10. C. Stoots, J. O'Brien, J. Hartvigsen, Results of recent high temperature coelectrolysis studies at the Idaho National Laboratory. Int. J. Hydrogen Energy. 34, 4208-4215 (2009).

11. M. B. Mogensen, M. Chen, H. L. Frandsen, C. Graves, J. B. Hansen, K. V. Hansen, A. Hauch, T. Jacobsen, S. H. Jensen, T. L. Skafte, X. Sun, Reversible solid-oxide cells for clean and sustainable energy. Clean Energy. 3, 175-201 (2019).

12. E. D. Wachsman, K. T. Lee, Lowering the Temperature of Solid Oxide Fuel Cells. Science, 334 (6058), 935-939 (2011).

13. M. B. Mogensen, Thermodynamics of high temperature $\mathrm{H}_{2} \mathrm{O}$ and $\mathrm{CO}_{2}$ electrolysis. doi 10.6084/m9.figshare.12652322 (2020).

14. S. Shiva Kumar, V. Himabindu, Hydrogen production by PEM water electrolysis - A review. Mater. Sci. Energy Technol. 2, 442-454 (2019).

15. M. Carmo, D. L. Fritz, J. Mergel, D. Stolten, A comprehensive review on PEM water electrolysis. Int. J. Hydrogen Energy. 38, 4901-4934 (2013).

16. S. Siracusano, V. Baglio, N. Van Dijk, L. Merlo, A. S. Aricò, Enhanced performance and durability of low catalyst loading PEM water electrolyser based on a short-side chain perfluorosulfonic ionomer. Appl. Energy. 192, 477-489 (2017).

17. C. Graves, S. D. Ebbesen, M. Mogensen, K. S. Lackner, Sustainable hydrocarbon fuels by recycling $\mathrm{CO}_{2}$ and $\mathrm{H}_{2} \mathrm{O}$ with renewable or nuclear energy. Renew. Sustain. Energy Rev. 15, 1-23 (2011).

18. R. Küngas, Review - Electrochemical $\mathrm{CO}_{2}$ Reduction for $\mathrm{CO}$ Production: Comparison of Low- and High-Temperature Electrolysis Technologies. J. Electrochem. Soc. 167, 044508 (2020).

19. P. C. K. Vesborg, T. F. Jaramillo, Addressing the terawatt challenge: scalability in the supply of chemical elements for renewable energy. RSC Adv. 2, 7933 (2012).

20. P. De Luna, C. Hahn, D. Higgins, S. A. Jaffer, T. F. Jaramillo, E. H. Sargent, What would it take for renewably powered electrosynthesis to displace petrochemical processes? Science. 364(6438), (2019), doi:10.1126/science.aav3506.

21. S. Verma, Y. Hamasaki, C. Kim, W. Huang, S. Lu, H.-R. M. Jhong, A. A. Gewirth, T. Fujigaya, N. Nakashima, P. J. A. Kenis, Insights into the Low Overpotential Electroreduction of $\mathrm{CO}_{2}$ to $\mathrm{CO}$ on a Supported Gold Catalyst in an Alkaline Flow Electrolyzer. ACS Energy Lett. 3, 193-198 (2018).

22. P. Hjalmarsson, X. Sun, Y.-L. Liu, M. Chen, Durability of high performance Ni-yttria stabilized zirconia supported solid oxide electrolysis cells at high current density. $J$. Power Sources. 262, 316-322 (2014).

23. A. Ploner, A. Hauch, S. Pylypko, S. Iorio, G. Cubizolles, J. Mougin, Optimization of Solid Oxide Cells and Stacks for reversible operation. ECS Transactions 91, 25172526 (2019), doi: 10.1149/09101.2517ecst. 
24. A. Hauch, S. H. Jensen, S. Ramousse, M. Mogensen, Performance and durability of solid oxide electrolysis cells. J. Electrochem. Soc. 153, 91-101 (2006), doi:10.1149/1.2216562.

25. X. Tong, S. Ovtar, K. Brodersen, P. V. Hendriksen, M. Chen, Large-area solid oxide cells with $\mathrm{La}_{0.6} \mathrm{Sr}_{0.4} \mathrm{CoO}_{3-\delta}$ infiltrated oxygen electrodes for electricity generation and hydrogen production. J. Power Sources. 451, 227742 (2020).

26. S. Ebbesen, M. B. Mogensen, Electrolysis of carbon dioxide in Solid Oxide Electrolysis Cells. J. Power Sources. 193, 349-358 (2009).

27. J. R. Wilson, W. Kobsiriphat, R. Mendoza, H.-Y. Chen, J. M. Hiller, D. J. Miller, K. Thornton, P. W. Voorhees, S. B. Adler, S. A. Barnett, Three-dimensional reconstruction of a solid-oxide fuel-cell anode. Nat. Mater. 5, 541-544 (2006).

28. S. Dierickx, J. Joos, A. Weber, E. Ivers-Tiffée, Advanced impedance modelling of Ni/8YSZ cermet anodes. Electrochim. Acta. 265, 736-750 (2018).

29. Z. Jiao, N. Shikazono, Study on the effects of polarization on local morphological change of nickel at active three-phase-boundary using patterned nickel-film electrode in solid oxide fuel cell anode. Acta Mater. 135, 124-131 (2017).

30. G. Rinaldi, S. Diethelm, E. Oveisi, P. Burdet, J. Van herle, D. Montinaro, Q. Fu, A. Brisse, Post-test Analysis on a Solid Oxide Cell Stack Operated for 10,700 Hours in Steam Electrolysis Mode. Fuel Cells (2017), doi:10.1002/fuce.201600194.

31. A. Hauch, K. Brodersen, M. Chen, M. B. Mogensen, Ni/YSZ electrodes structures optimized for increased electrolysis performance and durability. Solid State Ionics. 293, 27-36 (2016).

32. P. Khajavi, Y. Xu, H. L. Frandsen, J. Chevalier, L. Gremillard, R. Kiebach, P. V. Hendriksen, Tetragonal phase stability maps of ceria-yttria co-doped zirconia: From powders to sintered ceramics. Ceram. Int. 46, 9396-9405 (2020).

33. O. Posdziech, K. Schwarze, J. Brabandt, Efficient hydrogen production for industry and electricity storage via high-temperature electrolysis. Int. J. Hydrogen Energy. 44, 19089-19101 (2019).

34. G. Pećanac, J. Wei, J. Malzbender, Fracture toughness of solid oxide fuel cell anode substrates determined by a double-torsion technique. J. Power Sources. 327, 629-637 (2016).

35. D.-W. Ni, B. Charlas, K. Kwok, T. T. Molla, P. V. Hendriksen, H. L. Frandsen, Influence of temperature and atmosphere on the strength and elastic modulus of solid oxide fuel cell anode supports. J. Power Sources. 311, 1-12 (2016).

36. L. Blum, Q. Fang, S. M. Groß-Barsnick, L. G. J. (Bert) de Haart, J. Malzbender, N. H. Menzler, W. J. Quadakkers, Long-term operation of solid oxide fuel cells and preliminary findings on accelerated testing. Int. J. Hydrogen Energy. 45, 8955-8964 (2020).

37. T. Wood, H. He, T. Joia, in Proceedings of $12^{\text {th }}$ European SOFC \& SOE Forum,

38. J. Hartvigsen, S. Elangovan, J. Elwell, D. Larsen, in ECS Transactions, 78, 2953-2963 (2017).

39. S. B. Adler, Factors governing oxygen reduction in solid oxide fuel cell cathodes. Chem. Rev. 104, 4791-4843 (2004).

45 40. X. Tong, P. V. P. V. Hendriksen, A. Hauch, X. Sun, M. Chen, An Up-scalable, Infiltration-Based Approach for Improving the Durability of Ni/YSZ Electrodes for Solid Oxide Cells. ECS Transactions, 167, 024519 (2020).

41. Y. Cheng, A. S. Raman, J. Paige, L. Zhang, D. Sun, M. U. Chen, A. Vojvodic, R. J. Gorte, J. M. Vohs, Enhancing Oxygen Exchange Activity by Tailoring Perovskite Surfaces. J. Phys. Chem. Lett. 10, 4082-4088 (2019). 
42. H. Lv, L. Lin, X. Zhang, D. Gao, Y. Song, Y. Zhou, Q. Liu, G. Wang, X. Bao, In situ exsolved $\mathrm{FeNi}_{3}$ nanoparticles on nickel doped $\mathrm{Sr}_{2} \mathrm{Fe}_{1.5} \mathrm{Mo}_{0.5} \mathrm{O}_{6-\delta}$ perovskite for efficient electrochemical $\mathrm{CO}_{2}$ reduction reaction. J. Mater. Chem. A. 7, 11967-11975 (2019).

43. J. T. S. Irvine, D. Neagu, M. C. Verbraeken, C. Chatzichristodoulou, C. Graves, M. B. Mogensen, Evolution of the electrochemical interface in high-temperature fuel cells and electrolysers. Nat. Energy. 1, 15014 (2016).

44. A. Hauch, K. Brodersen, M. Chen, C. Graves, S. H. Jensen, P. S. Jørgensen, P. V. Hendriksen, M. B. Mogensen, S. Ovtar, X. Sun, A Decade of Solid Oxide Electrolysis Improvements at DTU Energy. ECS Transactions, 75, 3-14 (2017).

45. J. Schefold, A. Brisse, H. Poepke, 23,000 h steam electrolysis with an electrolyte supported solid oxide cell. Int. J. Hydrogen Energy, 42, 13415-13426 (2017), doi:10.1016/j.ijhydene.2017.01.072.

46. S. D. Ebbesen, C. Graves, A. Hauch, S. H. Jensen, M. Mogensen, Poisoning of Solid Oxide Electrolysis Cells by Impurities, J. Electrochem. Soc., 157(10), B1419 (2010),

47. T. L. Skafte, P. Blennow, J. Hjelm, C. Graves, Carbon deposition and sulfur poisoning during $\mathrm{CO}_{2}$ electrolysis in nickel-based solid oxide cell electrodes. J. Power Sources. 373, 54-60 (2018).

48. J. Wang, S. R. Bishop, L. Sun, Q. Lu, G. Vardar, R. Bliem, N. Tsvetkov, E. J. Crumlin, J. J. Gallet, F. Bournel, I. Waluyo, B. Yildiz, Threshold catalytic onset of carbon formation on $\mathrm{CeO}_{2}$ during $\mathrm{CO}_{2}$ electrolysis: Mechanism and inhibition. $J$. Mater. Chem. A. 7, 15233-15243 (2019).

49. R. Knibbe, M. L. Traulsen, A. Hauch, S. D. Ebbesen, M. Mogensen, Solid oxide electrolysis cells: Degradation at high current densities. J. Electrochem. Soc. 157(8), B1209-B1217 (2010), doi:10.1149/1.3447752.

50. Đ. Tripković, R. Küngas, M. B. Mogensen, P. V. Hendriksen, Surface recrystallization - an underestimated phenomenon affecting oxygen exchange activity. J. Mater. Chem. A. 7, 11782-11791 (2019).

51. J. Druce, H. Téllez, M. Burriel, M. D. Sharp, L. J. Fawcett, S. N. Cook, D. S. McPhail, T. Ishihara, H. H. Brongersma, J. A. Kilner, Surface termination and subsurface restructuring of perovskite-based solid oxide electrode materials. Energy Environ. Sci. 7, 3593-3599 (2014).

52. N. Tsvetkov, Q. Lu, L. Sun, E. J. Crumlin, B. Yildiz, Improved chemical and electrochemical stability of perovskite oxides with less reducible cations at the surface. Nat. Mater. 15, 1010-1016 (2016).

53. M. B. Mogensen, A. Hauch, X. Sun, M. Chen, Y. Tao, S. D. Ebbesen, K. V. Hansen, P. V. Hendriksen, Relation Between Ni Particle Shape Change and Ni Migration in Ni-YSZ Electrodes - a Hypothesis. Fuel Cells. 17, 434-441 (2017).

54. M. Trini, P. S. Jørgensen, A. Hauch, J. J. Bentzen, P. V Hendriksen, M. Chen, 3D Microstructural Characterization of Ni/YSZ Electrodes Exposed to 1 Year of Electrolysis Testing. J. Electrochem. Soc., 166, F158-F167 (2019).

55. M. Trini, A. Hauch, S. De Angelis, X. Tong, P. V. Hendriksen, M. Chen, Comparison of microstructural evolution of fuel electrodes in solid oxide fuel cells and electrolysis cells. J. Power Sources. 450, 227599 (2020), doi:10.1016/j.jpowsour.2019.227599.

56. S. D. Ebbesen, R. Knibbe, M. Mogensen, Co-Electrolysis of Steam and Carbon Dioxide in Solid Oxide Cells. J. Electrochem. Soc. 159, F482-F489 (2012).

57. A. Hauch, J. R. Bowen, L. T. Kuhn, M. Mogensen, Nanoscale chemical analysis and imaging of solid oxide cells. Electrochem. Solid-State Lett. 11(3), B38-B41(2008), doi: 10.1149/1.2828845.

58. T. Nakao, S. Inoue, S. Uenoyama, Y. Takuwa, M. Suzuki, Progress of SOFC Residential CHP System: Over 50,000 Units Market Experience of Osaka Gas. ECS 
Transactions, 91, 43-49 (2019).

59. T. L. Skafte, Quantitative review of degradation and lifetime of solid oxide cells and stacks. Proc. 12 ${ }^{\text {th }}$ Eur. SOFC \& SOE Forum 2016 (2016).

60. R. Küngas, Solid oxide electrolysis stack tests 2010-2019. Figshare,

DOI:10.6084/m9.figshare.12137112.

61. R. Küngas, SOEC plants 2015-2022. Figshare, DOI: 10.6084/m9.figshare.12661994.

62. N. P. Brandon, E. Ruiz-Trejo, P. Boldrin, Solid oxide fuel cell lifetime and reliability (Elsevier Academic Press, 2017).

63. P. Boldrin, N. P. Brandon, Progress and outlook for solid oxide fuel cells for transportation applications. Nat. Catal. 2, 571-577 (2019).

64. J. E. O’Brien, J. L. Hartvigsen, R. D. Boardman, J. J. Hartvigsen, D. Larsen, S. Elangovan, A $25 \mathrm{~kW}$ high temperature electrolysis facility for flexible hydrogen production and system integration studies. Int. J. Hydrogen Energy. 45, 15796-15804 (2020).

65. M. Riedel, M. P. Heddrich, K. A. Friedrich, Experimental Analysis of the CoElectrolysis Operation under Pressurized Conditions with a 10 Layer SOC Stack. $J$. Electrochem. Soc. 167, 024504 (2020).

66. S. H. Jensen, X. Sun, S. D. Ebbesen, M. Chen, Pressurized Operation of a Planar Solid Oxide Cell Stack. Fuel Cells. 16, 205-218 (2016).

67. M. Chen, X. Sun, A. Hauch et al., Final Report, Project no. 12013 Solid Oxide Electrolysis for Grid Balancing. (available at https://energiforskning.dk/en/node/7317 accessed July $17^{\text {th }} 2020$ ).

68. M. Rao, X. Sun, A. Hagen, Durability of solid oxide electrolysis stack under dynamic load cycling for syngas production. J. Power Sources. 451, 227781 (2020).

69. J. Schefold, A. Brisse, A. Surrey, C. Walter, 80,000 current on/off cycles in a one year long steam electrolysis test with a solid oxide cell. Int. J. Hydrogen Energy. 45, 51435154 (2020).

70. Project MultiPLHY - Multimegawatt high-temperature electrolyser to generate green hydrogen for production of high-quality biofuels. Grant Agreem. ID 875123; Horizon2020, Eur. Comm.

71. R. Küngas, P. Blennow, T. Heiredal-Clausen, T. Holt Nørby, J. Rass-Hansen, J. B. Hansen, P. G. Moses, Progress in SOEC Development Activities at Haldor Topsøe. ECS Trans. 91, 215-223 (2019).

72. J. B. Hansen, Solid oxide electrolysis - a key enabling technology for sustainable energy scenarios. Faraday Discuss. 182, 9-48 (2015).

73. J. B. Hansen, P. V. Hendriksen, The SOC4NH3 Project. Production and Use of Ammonia by Solid Oxide Cells. ECS Trans. 91, 2455-2465 (2019).

74. J. B. Hansen, SOEC-based systems for Power-to-X. DOI: 10.6084/m9.figshare.12652373 (2020).

40 75. C. Dannesboe, J. B. Hansen, I. Johannsen, Catalytic methanation of $\mathrm{CO}_{2}$ in biogas: experimental results from a reactor at full scale. React. Chem. Eng. 5, 183-189 (2020).

76. J. B. Hansen, F. Fock, H. H. Lindboe, Biogas Upgrading: By Steam Electrolysis or CoElectrolysis of Biogas and Steam. ECS Trans. 57, 3089-3097 (2013).

77. P. Böhm, H. Zauner, A. Goers, S. Tichler, R. Kroon, "Innovative large-scale energy storage technologies and Power-to-Gas concepts after optimization. D7.5: Report on experience curves and economies of scale" (2018).

78. P. Siegemund, S. Schmidt, https://www.dena.de/fileadmin/dena/Dokumente/Pdf/9219_E-FUELSSTUDY_The_potential_of_electricity_based_fuels_for_low_emission_transport_in_th e_EU.pdf (2017). 
79. L. Wang, M. Chen, R. Küngas, T.-E. Lin, S. Diethelm, F. Maréchal, J. Van herle, Power-to-fuels via solid-oxide electrolyzer: Operating window and techno-economics. Renew. Sustain. Energy Rev. 110, 174-187 (2019).

80. https://www.sunfire.de/en/company/news/detail/first-commercial-plant-for-theproduction-of-blue-crude-planned-innorway?file=files/sunfire/images/content/company/press/2017_sunfire_PR_NordicBlue-Crude.pdf. (Accessed $17^{\text {th }}$ July 2020)

81. C. H. Law, S. W. Sofie, Anchoring of Infiltrated Nickel Electro-Catalyst by Addition of Aluminum Titanate. J. Electrochem. Soc. 158, B1137 (2011).

82. W. Wang, L. Gan, J. P. Lemmon, F. Chen, J. T. S. Irvine, K. Xie, Enhanced carbon dioxide electrolysis at redox manipulated interfaces. Nat. Commun. 10 (2019), doi:10.1038/s41467-019-09568-1.

83. J. H. Myung, D. Neagu, D. N. Miller, J. T. S. Irvine, Switching on electrocatalytic activity in solid oxide cells. Nature. 537, 528-531 (2016).

84. Y. Wang, T. Liu, S. Fang, F. Chen, Syngas production on a symmetrical solid oxide $\mathrm{H}_{2} \mathrm{O} / \mathrm{CO}_{2}$ co-electrolysis cell with $\mathrm{Sr}_{2} \mathrm{Fe}_{1.5} \mathrm{Mo}_{0.5} \mathrm{O}_{6}-\mathrm{Sm}_{0.2} \mathrm{Ce}_{0.8} \mathrm{O}_{1.9}$ electrodes. J. Power Sources. 305, 240-248 (2016).

85. W. Dönitz, E. Erdle, R. Schaumm, R. Streicher, Recent Advances in the Development of High Temperature Electrolysis Technology in Germany. Adv. Hydrog. Energy. 6, 65-73 (1988).

86. R. Küngas, P. Blennow, T. Heiredal-Clausen, T. Holt Nørby, J. Rass-Hansen, P. G. Moses, Lifetime Capacity - An Important Performance Metric for SOEC Stacks. ECS Trans. 91, 2601-2611 (2019). 